\title{
Functional Expression of the New Gap Junction Gene Connexin47 Transcribed in Mouse Brain and Spinal Cord Neurons
}

\author{
Barbara Teubner, ${ }^{1}$ Benjamin Odermatt, ${ }^{1}$ Martin Güldenagel, ${ }^{1}$ Goran Söhl, ${ }^{1}$ Joachim Degen, ${ }^{1}$ \\ Feliksas F. Bukauskas, ${ }^{2}$ Jack Kronengold, ${ }^{2}$ Vytas K. Verselis, ${ }^{2}$ Yong Tae Jung, ${ }^{3}$ Christine A. Kozak, ${ }^{3}$ \\ Karl Schilling, ${ }^{4}$ and Klaus Willecke ${ }^{1}$ \\ 1/nstitut für Genetik, Universität Bonn, D-53117 Bonn, Germany, ${ }^{2}$ Department of Neuroscience, Albert Einstein College of \\ Medicine, New York, New York 10461, ${ }^{3}$ National Institute of Allergy and Infectious Diseases, National Institutes of Health, \\ Bethesda, Maryland 20892, and ${ }^{4}$ Anatomisches Institut, Universität Bonn, D-53115 Bonn, Germany
}

A new mouse gap junction gene that codes for a protein of 46,551 Da has been identified and designated connexin47 (Cx47). It mapped as a single-copy gene to mouse chromosome 11. In human HeLa cells and Xenopus oocytes, expression of mouse $\mathrm{C} \times 47$ or a fusion protein of $\mathrm{Cx} 47$ and enhanced green fluorescent protein induced intercellular channels that displayed strong sensitivity to transjunctional voltage. Tracer injections in Cx47-transfected HeLa cells revealed intercellular diffusion of neurobiotin, Lucifer yellow, and 4',6-diamidino-2phenylindole. Recordings of single channels yielded a unitary conductance of 55 pS main state and 8 pS substate. Cx47 mRNA expression was high in spinal cord and brain but was not found in retina, liver, heart, and lung. A low level of Cx47 expression was detected in ovaries. In situ hybridizations demonstrated high expression in $\alpha$ motor neurons of the spinal cord, pyramidal cells of the cortex and hippocampus, granular and molecular layers of the dentate gyrus, and Purkinje cells of the cerebellum as well as several nuclei of the brainstem. This expression pattern is distinct from, although partially overlapping with, that of the neuronally expressed connexin36 gene. Thus, electrical synapses in adult mammalian brain are likely to consist of different connexin proteins depending on the neuronal subtype.

Key words: Cx47; gap junctions; neuronal connexin; electrical synapses; voltage gating; permeability
Recent studies have described synaptic connections between neurons involving electrical transmission that appear to mediate their synchronized firing (Gibson et al., 1999; Galarreta and Hestrin, 2000; cf. Thomson, 2000). It is becoming evident that the incidence of electrical coupling in the mammalian CNS is much higher than thought previously, and a number of synapses exhibit the morphological correlates of both electrical and chemical transmission (Rash et al., 1996, 1998; Bennett, 2000). On the basis of results obtained by combining advanced microscopic techniques, electrophysiology, and theoretical modeling (Draguhn et al., 1998; Traub and Bibbig, 2000), a refined notion of electrical communication between neurons has to be considered. Networks of inhibitory interneurons in the cortex (Galarreta and Hestrin, 1999; Gibson et al., 1999) or hippocampus (Fukuda and Kosaka, 2000) are connected via axosomatic and dendrodendritic gap junctions.

The protein subunits of these channels are connexins, which form multimeric structures composed of either a single or multiple connexin isoforms. In rodents, 15 connexin genes have been described (Manthey et al., 1999; White and Paul, 1999). These

Received Sept. 21, 2000; revised Nov. 27, 2000; accepted Dec. 1, 2000.

This work was supported by Deutsche Forschungsgemeinschaft Grants SFB 400-B3 and WI 270/22-2, by the Fonds der Chemischen Industrie (K.W.), and by National Institutes of Health Grants NS367060 (F.F.B.) and NS07512 (V.K.V.). We thank Meike Weigel (Bonn) and Angele Bukauskiene (New York) for their excellent technical assistance.

Correspondence should be addressed to Dr. Klaus Willecke, Institut für Genetik, Abteilung Molekulargenetik, Römerstrasse 164, D-53117 Bonn, Germany. E-mail: genetik@uni-bonn.de.

Copyright (C) 2001 Society for Neuroscience 0270-6474/01/211117-10\$15.00/0 genes are developmentally regulated and expressed in a tissuespecific manner. Expression of connexin36 (Cx36) appears to occur almost exclusively in neurons and is highly abundant in mouse retina and brain (Condorelli et al., 1998; Söhl et al., 1998; Belluardo et al., 1999; Srinivas et al., 1999; Al-Ubaidi et al., 2000; Belluardo et al., 2000; Condorelli et al., 2000; Parenti et al., 2000; Teubner et al., 2000). Cx26, Cx32, and Cx43, which show widespread expression in non-neuronal tissues, also are expressed in some neurons (Dermietzel et al., 1989; Bittman and LoTurco, 1999; but see also Rash et al., 2000).

Functional gap junction channels are likely to be involved in tissue homeostasis of ions, metabolites, and second messenger molecules (Willecke et al., 1999). Between neuronal cells, these functions could play a role in synchronizing oscillations of certain cell clusters. This fine tuning of electric activity could have an impact on burst thresholds of electrotonically coupled cells (Sutor et al., 2000). In addition, neuronal gap junctions have been speculated to be involved in vesicle exocytosis (Yamamoto et al., 1990).

To understand finally the physiological relevance of electric coupling between neurons, one needs first to identify and characterize the molecular components with regard to developmental regulation and electrophysiological properties.

Here we describe cloning of the new mouse $\mathrm{Cx} 47$ gene that we have analyzed by Southern blot analysis, genomic mapping, and Northern blot analysis. In situ hybridization has shown that $\mathrm{Cx} 47$ RNA is expressed in several types of hippocampal, cortical, cerebellar, and spinal cord neurons but not in retinal cells. Furthermore, we have investigated the functional properties of mouse $\mathrm{Cx} 47$ and $\mathrm{Cx} 47$-enhanced green fluorescent protein 
(EGFP) channels expressed in Xenopus oocytes and human HeLa cells.

\section{MATERIALS AND METHODS}

PCR-mediated cloning of mouse Cx47. A database search yielded the genomic sequence of a human connexin, deposited as connexin 46.6 by B. K. Bloemker, A. Swaroop, and W. J. Kimberling (accession number AF014643), that exhibited the highest identity to a rat-expressed sequence tag (accession number AI144646). Two upstream PCR primers and one downstream PCR primer were deduced from the rat sequence avoiding similarities to the mouse $\mathrm{Cx} 45$ gene (46.6USP1CL, 5'-CCG GGG AAG ACA CGG AGG AGG-3'; 46.6USP2CL, 5'-TCA CTC CTG GCC CGG CCG GAC-3'; and 46.6DSP, 5'-CGC ACA GCG TCC TGC GCA CTG-3'). A PCR reaction was performed in a PTC-200 thermocycler (MJ Research, Watertown, MA) using $200 \mathrm{ng}$ of mouse genomic DNA (strain 129/ola) as template, 2 U of Taq DNA polymerase (Promega, Madison, WI) in the supplied buffer, $2 \mathrm{mM} \mathrm{MgCl}_{2}, 0.2 \mathrm{~mm}$ dNTPs, and $20 \mathrm{pmol}$ of either 46.6USP1CL or 46.6USP2CL and 46.6DSP as primers with the following program: $2 \mathrm{~min}, 94^{\circ} \mathrm{C} ; 40$ cycles of $30 \mathrm{sec}$, $94^{\circ} \mathrm{C} ; 1 \mathrm{~min}, 58^{\circ} \mathrm{C}$; and $1 \mathrm{~min}, 72^{\circ} \mathrm{C}$. The PCR products $(\sim 400$ or $\sim 350 \mathrm{bp}$ with 46.6USP1CL and 46.6DSP or with 46.6USP2CL and 46.6DSP, respectively) were cloned into pGEM-T easy (Promega) and sequenced.

The $400 \mathrm{bp}$ PCR product was used as a probe in a phage library screen (129/SvJ mouse genomic DNA in $\lambda$ fixII; Stratagene, La Jolla, CA) as described (Söhl et al., 1998). Two phage clones were isolated under stringent conditions, and restriction fragments generated with HindIII, NotI, or $X b a \mathrm{I}$ were subcloned into pBluescriptIISK ${ }^{+}$(Stratagene) and sequenced. The sequence analysis yielded a new connexin gene, called connexin47 (see below).

Plasmids. For stable transfection of HeLa cells, the coding region of mouse $\mathrm{Cx} 47$ was PCR amplified from phage DNA and cloned into the expression vectors pBEHpac18 (Horst et al., 1991) and pEGFP-N1 (Clontech, Palo Alto, CA), to construct a fusion protein of the $\mathrm{Cx} 47$ sequence with the enhanced green fluorescent protein at its $\mathrm{C}$ terminal. The primers had a $K p n \mathrm{I}$ site at the $\mathrm{N}$ terminal (primer KPNATG, 5'-GGG GTA CCG ACC AAC ATG AGC TGG AGC TTC C-3') and a BamHI site behind the stop codon of the connexin gene (primer BAMSTOP, 5'-GCA GGA TCC TCA GAT CCA CAC GGT GGC-3') or, in the case of the fusion protein, a BamHI site instead of the stop codon of the $\mathrm{Cx} 47$ gene (primer BAMGO, 5'-GCG GAT CCG CGA TCC ACA CGG TGG CCT TGC-3'). The PCR products were cloned with $K p n I$ and BamHI into pBEHpac18 and pEGFP-N1 and sequenced; the resulting expression plasmids were named $\mathrm{pCx} 47$ and $\mathrm{pCx} 47 \mathrm{EGFP}$.

For expression in Xenopus oocytes, the $\mathrm{Cx} 47$-coding region was PCR amplified and cloned into pBluescriptIISK ${ }^{+}$(Stratagene). The primers had a KpnI site at the $\mathrm{N}$ terminal (primer KPNATG, 5'-GGG GTA CCG ACC AAC ATG AGC TGG AGC TTC C-3') and a BamHI site behind the stop codon of the connexin gene (primer BAMSTOP, 5'-GCA GGA TCC TCA GAT CCA CAC GGT GGC-3'). The PCR product was cloned with $\mathrm{KpnI}$ and BamHI into pBluescriptIISK ${ }^{+}$and sequenced.

Southern blot analysis. Mouse genomic DNA (129/ola) was digested with either BglII, EcoRI, HindIII, PstI, or $X b a \mathrm{I}$, separated by electrophoresis in an $0.8 \%$ agarose gel, blotted onto nylon membranes, and hybridized under stringent conditions, as described (Söhl et al., 1998), to the labeled 400 bp PCR product containing part of the Cx47-coding region.

Genetic mapping. The mouse $C x 47$ gene was mapped by analysis of the progeny of the multilocus cross: $(\mathrm{NFS} / \mathrm{N} \times$ Mus spretus $) \times M$. spretus or C58/J (Adamson et al., 1991). Recombinational distances were calculated according to Green (1981), and gene loci were ordered by minimizing the number of recombinants.

Northern blot analysis. Total RNA was prepared from C57BL/6 mouse tissues with the TRIzol reagent (Life Technologies, Eggenstein, Germany) according to instructions of the manufacturer. The RNA was separated by electrophoresis in an agarose gel, blotted onto nylon membranes, and hybridized under stringent conditions as described (Söhl et al., 1998) to a labeled $1.6 \mathrm{~kb} \mathrm{XbaI}$ fragment containing part of the $\mathrm{Cx} 47$-coding region and $3^{\prime}$-untranslated region.

In situ hybridization. Cx47 mRNA localization was analyzed using cryosections $(10 \mu \mathrm{m})$ of brain and spinal cord from adult C57/BL6 mice. To exclude cross-reaction with other connexin mRNAs, sections of other tissues were coanalyzed (liver, retina, heart, and kidney; data not shown).

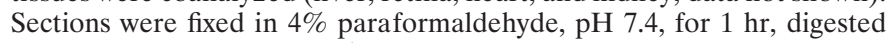
with $4 \mu \mathrm{g} / \mathrm{ml}$ Proteinase K (Roche Molecular Biochemicals, Mannheim, Germany) in PBS for $30 \mathrm{~min}$ at $37^{\circ} \mathrm{C}$, and post-fixed in $4 \%$ paraformal- dehyde for $20 \mathrm{~min}$. Specimens were then incubated in acetylation buffer $(0.25 \%$ acetic anhydride in $0.1 \mathrm{~m}$ triethanolamine, $\mathrm{pH} 8.0)$. After dehydration in 50,70, and $96 \%$ ethanol, sections were air-dried and prehybridized at $48^{\circ} \mathrm{C}$ for $1 \mathrm{hr}$ in hybridization solution [ $40 \%$ formamide, $10 \%$ dextran sulfate, $1 \times$ Denhardt's solution (Sigma, Deisenhofen, Germany), $4 \times$ SSC, $0.2 \%$ DTT, $0.1 \mathrm{mg} / \mathrm{ml}$ yeast tRNA, and $0.5 \mathrm{mg} / \mathrm{ml}$ herring sperm DNA]. For in vitro transcription, the digoxigenin-3-o-methylcarbonyl- $\epsilon$-aminocaproic acid-N (DIG) RNA-labeling kit (Roche Molecular Biochemicals) was used with the $400 \mathrm{bp} \mathrm{Cx} 47$ PCR product cloned in pGEM-T easy (see above) as template. The labeled probe corresponded to nucleotides 482-884 (counted from the ATG start codon), either transcribed in sense or antisense orientation, using T7 or SP6 polymerases, respectively. Sections were hybridized at $48^{\circ} \mathrm{C}$ overnight with hybridization solution containing $5 \mathrm{ng} / \mathrm{ml}$ DIG-labeled riboprobe. The next day, sections were successively washed with $4 \times, 2 \times, 1 \times$, and $0.5 \times \mathrm{SSC}$ at $48^{\circ} \mathrm{C}$ for $10 \mathrm{~min}$. To remove the remaining probe, sections were digested at $37^{\circ} \mathrm{C}$ for $30 \mathrm{~min}$ with $20 \mu \mathrm{g} / \mathrm{ml}$ ribonuclease in $0.5 \mathrm{M}$ $\mathrm{NaCl}, 10 \mathrm{~mm}$ Tris, $\mathrm{pH} 8.0$, and $1 \mathrm{~mm}$ EDTA and washed in $0.5 \times \mathrm{SSC}$ for $10 \mathrm{~min}$ at $48^{\circ} \mathrm{C}$. To detect DIG-labeled riboprobes, sections were blocked with $4 \%$ BSA and $0.1 \%$ Triton X-100 in Tris-buffered saline, $\mathrm{pH} 8.0$, and incubated with alkaline phosphatase-conjugated anti-DIG Fab fragments (Roche Molecular Biochemicals). After washing with Tris-buffered saline, $\mathrm{pH}$ 9.0, sections were incubated overnight in substrate solution (nitro-blue tetrazolium/5-bromo-4-chloro-3-indolylphosphate). The colorimetric reaction for alkaline phosphatase was stopped after microscopic examination. Images were prepared for publication using Adobe Photoshop 5.5 software.

Cell culture, transfection, and expression in Xenopus oocytes. HeLa cells (American Type Culture Collection CCL 2, human cervical carcinoma cells) were cultivated in DMEM low glucose, $2 \mathrm{~mm}$ glutamine, $10 \%$ fetal calf serum, and $1 \times$ penicillin and streptomycin (all from Life Technologies) at $37^{\circ} \mathrm{C}$ with $10 \% \mathrm{CO}_{2}$ and transfected with the two $\mathrm{Cx} 47$ expression plasmids $\mathrm{pCx} 47$ and $\mathrm{pCx} 47 \mathrm{EGFP}$ using Tfx20 (Promega). Resistant clones were isolated after 2 weeks of selection with $1 \mu \mathrm{g} / \mathrm{ml}$ Puromycin (Sigma) or $1 \mathrm{mg} / \mathrm{ml} \mathrm{G} 418$ (Life Technologies) and tested for Cx47EGFP expression by microscopy with an excitation wavelength of $488 \mathrm{~nm}$. In the case of Cx47 without EGFP, the clones were tested by neurobiotin injection (see below).

Cx47-coding DNA was cloned into the expression vector pBluescriptIISK $^{+}$(Stratagene) in the T7 orientation. Cx47 RNA was prepared with the mMessage mMachine kit from Ambion (Austin, TX). Each oocyte was injected with $50 \mathrm{nl}$ of $\mathrm{Cx} 47 \mathrm{RNA}(\sim 1 \mu \mathrm{g} / \mu \mathrm{l})$ together with the phosphorothionate antisense oligonucleotide $(\sim 0.5 \mathrm{pmol} / \mathrm{nl}) 5^{\prime}$-GCT TTA GTA ATT CCC ATC CTG CCA TGT TTC-3', which is complementary to the Xenopus $\mathrm{Cx} 38$ sequence starting at nucleotide 5 .

Tracer transfer measurements. Cells were grown on $35 \mathrm{~mm}$ dishes for 2-3 d. Glass micropipettes were pulled from capillary glass (World Precision Instruments, Berlin, Germany) with a horizontal pipette puller (model P-97; Sutter Instruments Company, Novato, CA) and backfilled with tracer solution (see below). Tracers were injected iontophoretically (Iontophoresis Programmer model 160; World Precision Instruments), and cell-to-cell transfer was monitored using an inverted microscope (IM35; Zeiss) equipped with fluorescent illumination. Cell culture dishes were kept on a heated block at $37^{\circ} \mathrm{C}$. Lucifer yellow $\mathrm{CH}$ (Molecular Probes, Eugene, OR) at $4 \%$ (w/v) in $1 \mathrm{~m} \mathrm{LiCl}$ or 4',6-diamidino-2phenylindole, dihydrochloride (DAPI; Roche Molecular Biochemicals) at $25 \mathrm{~mm}$ in $0.2 \mathrm{M} \mathrm{LiCl}$ was injected by applying hyperpolarizing currents for $10 \mathrm{sec}(I=20 \mathrm{nA})$ or depolarizing currents for $10 \mathrm{sec}(I=20 \mathrm{nA})$ in the case of DAPI. Intercellular transfer of tracers was evaluated $10 \mathrm{~min}$ after injection. $\mathrm{N}$-2(2-aminoethyl)-biotinamide hydrochloride (Neurobiotin; Vector Laboratories, Burlingame, CA) and rhodamine 3 -isothiocyanate dextran 10S (Sigma) at concentrations of 6 and $0.4 \%$ $(\mathrm{w} / \mathrm{v})$, respectively, in $0.1 \mathrm{M}$ Tris-Cl, $\mathrm{pH}$ 7.6, were injected by applying depolarizing currents for $10 \mathrm{sec}(I=20 \mathrm{nA})$. Ten minutes after injection, cells were washed twice with PBS, fixed for $10 \mathrm{~min}$ in $1 \%$ glutaraldehyde in PBS, washed twice with PBS, incubated in 2\% Triton X-100 in PBS overnight at $4^{\circ} \mathrm{C}$, washed three times with PBS, incubated with horseradish peroxidase-avidin D (Vector Laboratories) diluted 1:1000 in PBS for 90 min, washed three times with PBS, and incubated in $0.05 \%$ diaminobenzidine and $0.003 \%$ hydrogen peroxide solution for $30 \mathrm{sec}$. Immediately thereafter, the staining reaction was stopped by washing three times with PBS. Cell-to-cell transfer was quantified by counting the total number of stained neighboring cells around the microinjected cell.

Additional studies assessed junctional conductance and dye transfer in the same cell pairs. In these studies Lucifer yellow (negatively charged, 
-2 ) or DAPI (positively charged, +2) was used. In each experiment, dye was delivered to one cell of a pair by establishing a whole-cell recording using a pipette filled with $0.1 \%$ dye diluted in normal pipette solution. After allowing sufficient time for dye transfer (5-10 min), a whole-cell voltage-clamp recording was established in the recipient cell to measure $g_{j}$. Fluorescence signals were monitored using a MERLIN imaging system equipped with an UltraPix FE250 cooled digital camera (12 bit), a xenon lamp source, and a SpectraMaster high-speed monochromator (Olympus America, Melville, NY). Dye distribution was monitored by acquiring images every $5 \mathrm{sec}(0.5 \mathrm{sec}$ exposures) over a period of $15 \mathrm{~min}$. Electronic shuttering of the digital camera allowed the setting of exposure times and timing intervals between fluorescence measurements.

Electrophysiological measurements. HeLa cells transfected with $\mathrm{pCx} 47$ or pCx47EGFP were seeded on $22 \times 22 \mathrm{~mm}$ No. 0 coverslips (Clay Adams) and transferred to an experimental chamber mounted on the stage of an inverted microscope equipped with phase-contrast optics. The chamber was perfused with a modified solution of Krebs-Ringer containing (in mM): $\mathrm{NaCl}, 140 ; \mathrm{KCl}, 4 ; \mathrm{CaCl}_{2}, 2 ; \mathrm{MgCl}_{2}, 1$; glucose, 5; pyruvate, 2; and HEPES, 5, $\mathrm{pH}$ 7.4. Patch pipettes were filled with a solution containing (in $\mathrm{mM}$ ): $\mathrm{KCl}, 130$; sodium aspartate, $10 ; \mathrm{MgCl}_{2}, 1$; $\operatorname{MgATP}, 3 ; \mathrm{CaCl}_{2}, 0.26$; EGTA, $2\left(\left[\mathrm{Ca}^{2+}\right]_{\mathrm{i}}=5 \times 10^{-8} \mathrm{M}\right)$; and HEPES, $5, \mathrm{pH}$ 7.2. Junctional conductance $g_{j}$ was measured using the dual wholecell patch-clamp method (Neyton and Trautmann, 1985). After establishment of whole-cell patch-clamp recordings in both cells of a pair, the cells were clamped to a common holding potential $\left(V_{1}=V_{2}\right)$. Transjunctional voltages $V_{j}$ were applied by changing the membrane potential in one cell and keeping the other constant $\left(V_{j}=V_{2}-V_{1}\right)$. The resulting junctional current $I_{j}$ was observed as a change in current in the unstepped cell. $G_{j}$ was determined from $I_{j} / V_{j}$. Voltages and currents were recorded on videotape using a data recorder, VR-100 (Instrutech Corporation, Port Washington, NY), and were subsequently digitized using a MIO16X analog-to-digital (A/D) converter (National Instruments, Austin, TX) and our own acquisition software.

Recordings of $\mathrm{Cx} 47$ junctional currents between Xenopus oocyte cell pairs were obtained with a dual two-electrode voltage clamp using two GeneClamp 500 amplifiers (Axon Instruments). Approximately $24-36 \mathrm{hr}$ after injection, oocytes were devittelinized and paired. The procedures and solutions used for devittelinization, pairing, filling, voltage recording, and current-passing electrodes have been described previously $(\mathrm{Ru}-$ bin et al., 1992; Verselis et al., 1994). $G_{j}$ was measured as described above in dual whole-cell patch clamp by dividing the current measured in the unstepped cell by the voltage difference between the cells. $V_{j}$ steps were applied over a range of $\pm 120 \mathrm{mV}$ in $10 \mathrm{mV}$ increments; the cells were allowed to recover for $90-120 \mathrm{sec}$ between $V_{j}$ steps. Because expression over the course of some experiments increased, for each cell pair, a small, brief prepulse of constant amplitude $(10 \mathrm{mV})$ preceded each $V_{j}$ step so that a family of currents could be normalized. The currents were digitized at $1 \mathrm{kHz}$. Initial and steady-state currents were obtained by extrapolating exponential fits of the data to $t=0$ and $t=\infty$ as described (Verselis et al., 1994). Only cell pairs with $g_{j}$ values not exceeding $5 \mu \mathrm{S}$ were used to avoid effects of series access resistance on voltage dependence (Wilders and Jongsma, 1992). Data were digitized using a MIO16X A/D converter and our own acquisition software.

\section{RESULTS}

\section{Cloning, genomic mapping, and sequence analysis of mouse Cx47}

As described in Materials and Methods, we cloned by PCR part of a mouse connexin sequence homologous to a human connexin sequence designated human connexin 46.6 (accession number AF014643) in the data library. A genomic mouse DNA phage library was screened using this PCR product as a probe, and two independent clones were purified under conditions of high stringency. The open reading frame encoded a protein of 437 amino acids and showed the typical features of a connexin: four putative transmembrane spanning domains and three cysteines at the conserved positions of the two putative extracellular loops. The theoretical molecular mass of this protein was $46,551 \mathrm{Da}$, and thus it was named mouse $\mathrm{Cx} 47$, following a previous system for connexin nomenclature (Beyer and Willecke, 2000).

$C \times 47$ is a single-copy gene in the mouse genome, as revealed by
Southern blot analysis. The $400 \mathrm{bp}$ Cx 47 PCR product was used as a probe, and labeled fragments of $6.5,>12,4.5,0.8$, and $1.6 \mathrm{~kb}$ were obtained after digestion of mouse 129/ola DNA with BglII, EcoRI, HindIII, PstI, and XbaI, respectively (data not shown).

$P v u I I$ digestion gave rise to fragments of $1.7 \mathrm{~kb}$ in $M$. spretus and $\mathrm{C} 58 / \mathrm{J}$ mice and $1.2 \mathrm{~kb}$ in $\mathrm{NFS} / \mathrm{N}$ mice. Inheritance of the variant fragments was followed in the progeny of the genetic cross and indicated that $C x 47$ mapped to chromosome 11 with the following order and recombinational distances: Canx, Mgat1 $(3.0 \pm 1.7) \rightarrow$ Gm2a, Hspa4, Irf1 $(2.8 \pm 1.9) \rightarrow$ Cx47, Aldh3, Aldh4 $(8.7 \pm 3.4) \rightarrow$ Shbg, Myhs.

In a database comparison, we found the human $\mathrm{Cx} 46.6$ sequence and the mouse $\mathrm{Cx} 45$ sequence to be most similar to that of mouse $\mathrm{Cx} 47$ (see Fig. 1). Human Cx46.6 and mouse $\mathrm{Cx} 47$ share $84 \%$ identical amino acid residues, whereas the identity between mouse $\mathrm{Cx} 45$ and $\mathrm{Cx} 47$ amino acid sequences is $49 \%$. Mouse Cx36 that has been grouped either in the $\gamma$ (O'Brien et al., 1998) or $\delta$ (Söhl et al., 1998) class of connexins was included in this comparison because of its neuronal expression pattern and its unusually long cytoplasmic loop (Condorelli et al., 1998; Söhl et al., 1998). The identity of the amino acid sequences between mouse $\mathrm{Cx} 36$ and $\mathrm{Cx} 47$ is $40 \%$, but this degree of homology is similar to that of other connexins of the $\alpha$ or $\beta$ class and $\mathrm{Cx} 47$. Therefore, we suggest that the newly cloned $\mathrm{Cx} 47$ gene should be tentatively classified together with $\mathrm{Cx} 45$ into the $\gamma$ subgroup of connexins (Goodenough et al., 1996; Söhl et al., 1998).

\section{Expression pattern and developmental regulation of $\mathrm{Cx} 47$}

The tissue distribution of $\mathrm{Cx} 47$ mRNA was determined by Northern blot analysis. In brain, spinal cord, and ovaries, the $\mathrm{Cx} 47$ probe hybridized to an RNA of $2.5 \mathrm{~kb}$. No signal was detected in the retina, sciatic nerve, liver, lung, and heart (Fig. 2a). The mRNA of the most closely related connexin sequence, mouse $\mathrm{Cx} 45$, has a length of $2.2 \mathrm{~kb}$; moreover, the expression patterns of these genes differ considerably (cf. Hennemann et al., 1992). Therefore, cross-hybridization of the $\mathrm{Cx} 47$ probe to this or other known connexin mRNAs can be excluded. Because the level of expression of several connexin mRNAs is modulated during brain development (cf. Prime et al., 2000), Cx47 expression was analyzed by Northern blotting in RNA preparations obtained from whole brains of prenatal and postnatal mice (Fig. 2b). Cx47 transcription was first detected 1 week after birth and reached a maximum 2 weeks after birth. In the adult mouse, Cx47 mRNA levels decreased again to approximately one-third of the level seen in 2-week-old animals.

In situ hybridization analysis confirmed the widespread expression of $\mathrm{Cx} 47$ within the CNS and revealed that labeling was restricted to cells within areas of gray matter in the brain and spinal cord (Fig. $3 A, D, J, M$ ). Specifically, no labeling was seen over the white matter of the spinal cord, the forebrain, the cerebellum, and the corpus callosum. In a first attempt to define the cell type(s) in which $\mathrm{Cx} 47$ is expressed, we scrutinized sections of the forebrain, the hippocampal formation, the brainstem, the cerebellum, and the spinal cord. Strong and specific signals were found over numerous cells of the neocortical gray matter, with particularly prominent labeling of the triangular profiles of pyramidal neurons (Fig. $3 E$ ). In the hippocampal formation both pyramidal cells of the cornu Ammonis (CA1-CA4) and granule cells of the dentate gyrus were prominently labeled (Fig. $3 D, G, H)$. In addition, a few cells within the stratum oriens, the stratum radiatum, and the stratum lacunosum-moleculare were 


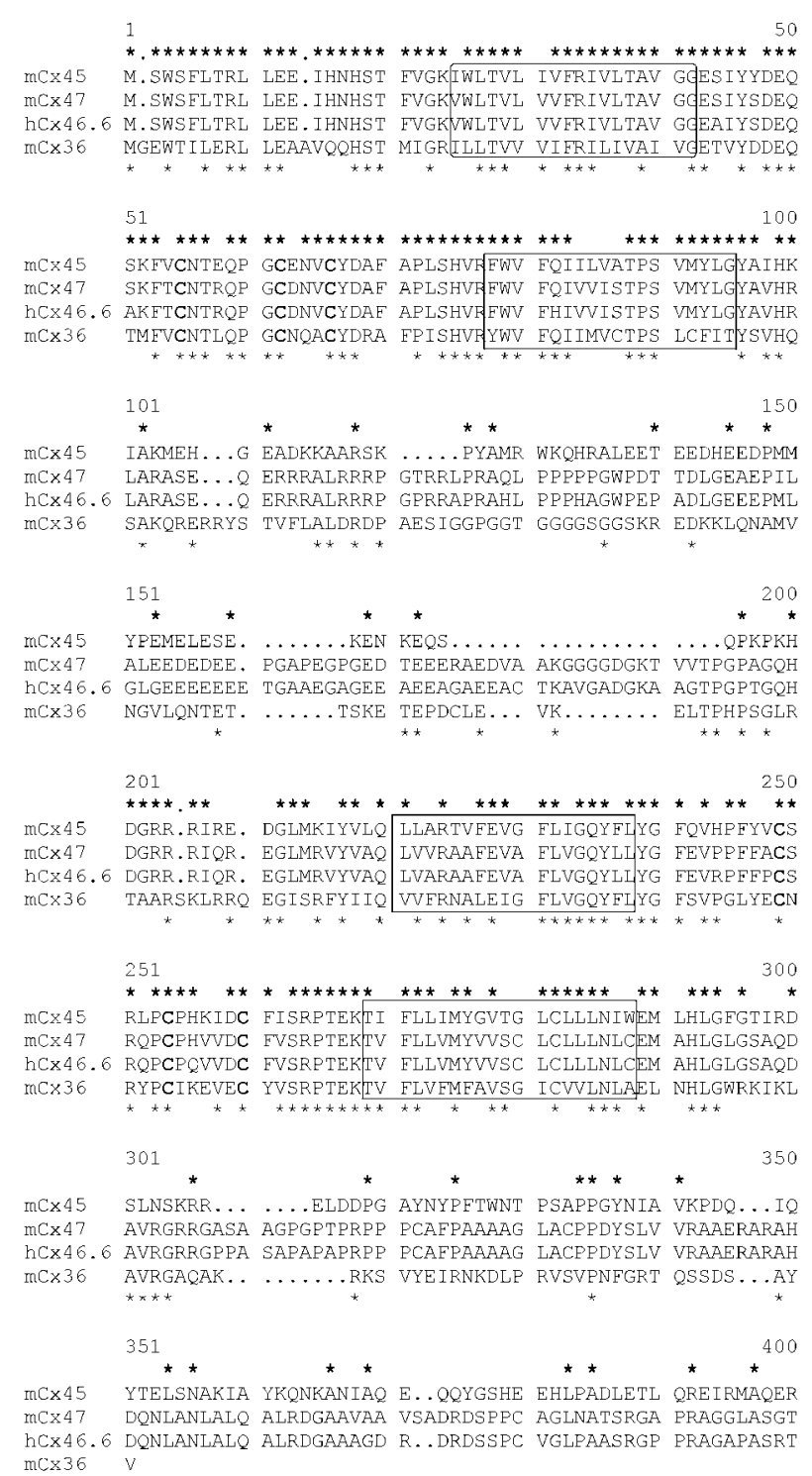
$\operatorname{mcx} 36$ v

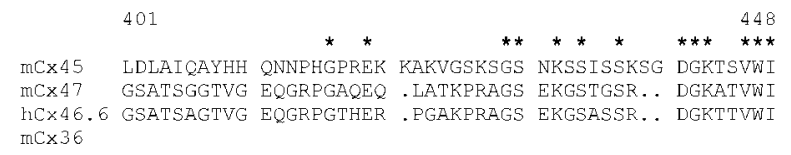

Figure 1. The peptide sequences of mouse Cx45 (Hennemann et al., 1992), mouse Cx47 (accession number AJ276435), human Cx46.6 (accession number AF014643), and mouse Cx36 (Condorelli et al., 1998) were aligned. The conserved cysteine residues are printed bold, and the core putative transmembrane domains are boxed. Identical amino acid residues between $\mathrm{Cx} 47$ and $\mathrm{Cx} 45$ or between $\mathrm{Cx} 47$ and $\mathrm{Cx} 36$ are marked with an asterisk above or below the sequences, respectively. The nucleotide sequence data of mouse $\mathrm{Cx} 47$ are available from European Molecular Biology Laboratory under accession number AJ276435.

labeled (Fig. 3H). Although the latter cells cannot be unambiguously identified without resorting to double staining with specific markers, we note that the localization and number of these cells are consistent with their tentative identification as hippocampal interneurons.

Within the cerebellum, unambiguous labeling could be seen over the granule cell layer and the Purkinje cell layer. Besides labeled granule cells, the granule cell layer contained scattered positive cells that were larger than granule cells and displayed a
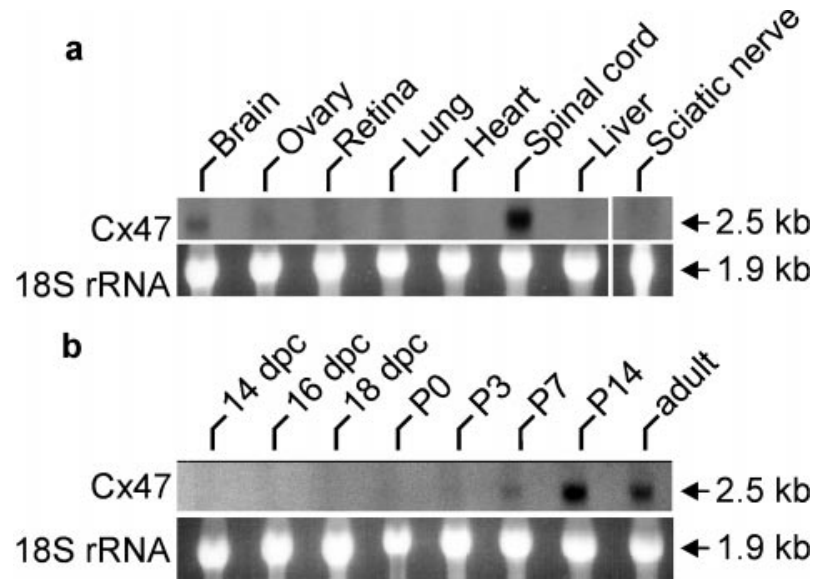

Figure 2. $a, b$, Top, Northern blot analysis of $\mathrm{Cx} 47$ expression in adult mouse tissues $(a)$ and eight stages of mouse brain development $(b)$ are shown. Bottom, Equal amounts of total RNA were loaded as demonstrated by staining of $18 \mathrm{~S}$ ribosomal RNA with ethidium bromide (bottom). The size of the bands is indicated in kilobases on the right. P0, Postnatal day 0; $d p c$, dies postcoitum.

prominent cytoplasm, suggestive of Golgi neurons. Basket and stellate cells within the molecular layer were not labeled by the Cx47 probe (Fig. 3B). Within the brainstem, labeling of the nucleus hypoglossus, nucleus reticularis, and the inferior olive was particularly prominent (Fig. $3 J, K$ ). The labeling seen in the spinal cord is documented in Figure 3, $M$ and $N$. Again, labeled cells were restricted to the gray matter, and the label was particularly abundant over large triangular and multiangular cells in the ventral horn of the gray matter. Both the position and the size of these cells allow their identification as motor neurons. In control experiments using a sense probe and performed on consecutive sections, none of the above labeling was seen (Fig. 3C,F,I,L,O).

\section{Functional properties of the $\mathbf{C x 4 7}$ channels}

\section{Electrical cell-cell coupling}

The ability of $\mathrm{Cx} 47$ to induce electrical coupling was tested in pairs of Xenopus oocytes injected with Cx47 cRNA and in HeLa cells transfected with $\mathrm{Cx} 47$ and $\mathrm{Cx} 47-\mathrm{EGFP}$. Pairs of Xenopus oocytes injected with $\mathrm{Cx} 47 \mathrm{cRNA}$ and antisense oligonucleotides to the endogenous $X e n C x 38$ exhibited high levels of electrical coupling with a mean $g_{j}$ of $17.6 \pm 6.3 \mu \mathrm{S} 12-18 \mathrm{hr}$ after pairing $(n=11)$. Control oocytes from the same frogs injected with antisense oligonucleotides alone showed very low coupling $(<0.1 \pm 0.04 \mu \mathrm{S} ; n=6)$. Similarly, HeLa-Cx47-EGFP cell pairs that exhibited punctate fluorescent staining at locations of cellcell contact were electrically coupled with a mean $g_{j}$ of $9.3 \pm 5.1$ $\mathrm{nS}(n=12)$. The strength of coupling in HeLa cells correlated with the number and size of fluorescent plaques.

\section{Voltage gating}

The dependence of $g_{j}$ on $V_{j}$ was examined both in Xenopus oocyte pairs and in HeLa-Cx47-EGFP cell pairs. Normalized initial and steady-state $g_{j}-V_{j}$ relations obtained from Xenopus oocytes are plotted in Figure $4 A$. Data were obtained by polarizing one cell of a pair to positive and negative voltages. Initial $G_{j}$ (filled triangles) is nearly constant with $V_{j}$, declining only modestly $(\sim 10 \%)$ over a $\pm 120 \mathrm{mV}$ range. Steady-state $G_{j}$ (open triangles) decreases steeply and symmetrically at approximately $V_{j}=0$. Most of the decrease in $G_{j}$ occurs over an $\sim 40 \mathrm{mV}$ range, between \pm 40 and $\pm 80 \mathrm{mV}$, and reaches a nonzero plateau con- 


\section{Cx47 antisense}
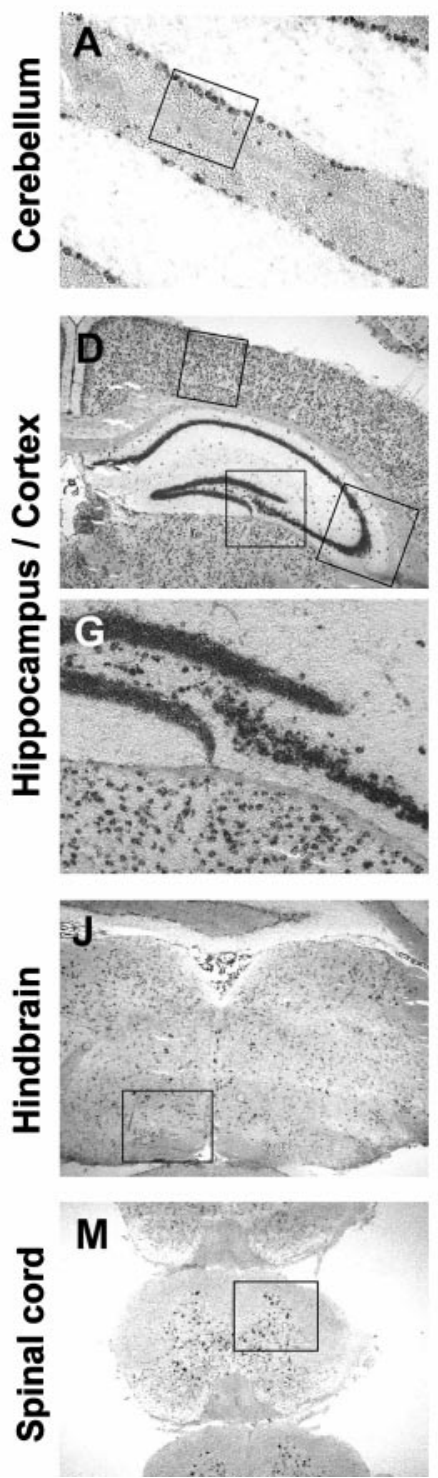
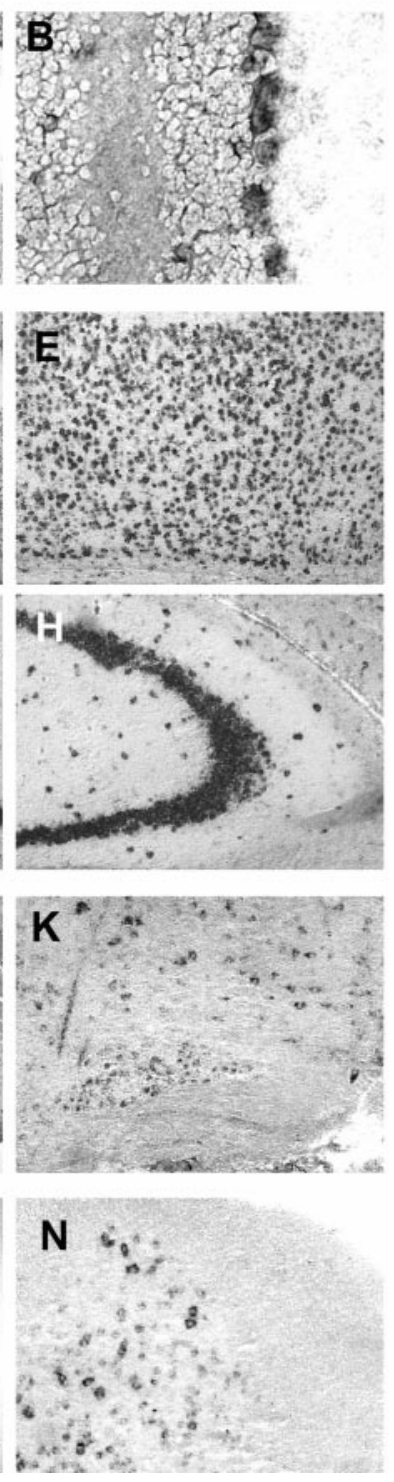

\section{Cx47 sense}
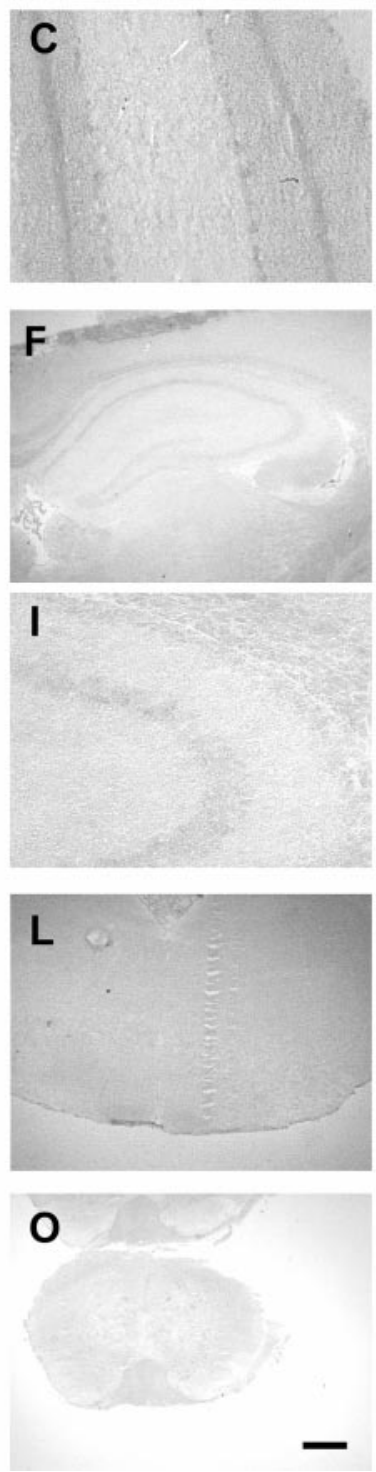

Figure 3. Expression of $\mathrm{Cx} 47 \mathrm{mRNA}$ in the murine CNS. Coronal sections of adult brain and spinal cord were hybridized as described in Materials and Methods. Representative sections from the cerebellum $(A-C)$, forebrain $(D-I)$, hindbrain $(J-L)$, and spinal cord $(M-O)$ are shown. Note that the in situ signal labels preferentially and/or cell layers known to contain specific neuronal phenotypes, such as the Purkinje cell layer and the granule cell layers in the cerebellum $(A, B)$. Within the hippocampal formation $(D, G, H)$, heavy labeling is seen over the dentate gyrus $(G)$ and all subregions of the cornu Ammonis ( $D, H$; the latter micrograph depicts the CA3 region). Within the cerebral cortex $(D, E)$, numerous cells located in all cell layers are positive. In the brainstem, labeling was particularly prominent over nuclei, such as the inferior olive $(J, K)$. The micrographs from the cervical spinal cord $(M, N)$ again show numerous labeled cells within the gray matter and also document that oligodendrocytes and astrocytes within the white matter do not express detectable levels of $\mathrm{Cx} 47$ mRNA. Sections shown in $A, B, D, E, G, H, J$, $K, M$, and $N$ were hybridized with the $\mathrm{Cx} 47$ antisense probe. Controls shown in $C, F, I, L$, and $O$ were hybridized with a $\mathrm{Cx} 47$ sense probe. Rectangles in micrographs $A, D, J$, and $M$ indicate the areas from which the higher power views shown in $B, E, G, H, K$, and $N$, respectively, were taken. Scale bar: $A, C, E, G-I, K, N$, $100 \mu \mathrm{m} ; B, 25 \mu \mathrm{m} ; D, F, J, L, M, O, 400 \mu \mathrm{m}$. ductance, $G_{\min }$, that is $\sim 15 \%$ of the maximum $G_{j}$. The steadystate $G_{j}-V_{j}$ relation was fit to a Boltzmann relation of the form: $G_{j}=\left\{\left(1-G_{\min }\right) /\left(1+\exp \left[A\left(V_{j}-V_{0}\right)\right]\right)\right\}$, where for each polarity of $V_{j}, V_{0}$ corresponds to the $V_{j}$ at which $G_{j}$ is half-maximum, $A$ characterizes the steepness of $V_{j}$ dependence, and $G_{\min }$ is the residual plateau $G_{j}$ at large $V_{j}$ values. The Boltzmann parameters are as follows: $V_{0}= \pm 51 \mathrm{mV}, A=0.2 \mathrm{mV}^{-1}$, and $G_{\min }=0.16$. If a simple two-state model for gating for each polarity of $V_{j}$ is assumed, a value of $\sim 0.2 \mathrm{mV}^{-1}$ for $A$ gives a calculated gating charge of approximately five elementary charges moving across the entire transjunctional field. Representative junctional currents reveal relatively fast kinetics with time constants $<100 \mathrm{msec}$ at $V_{j}$ values exceeding $\pm 100 \mathrm{mV}$ (Fig. $4 B$ ).

The steady-state $G_{j}-V_{j}$ relations obtained in HeLa cell pairs stably tranfected with $\mathrm{Cx} 47$ and $\mathrm{Cx} 47$-EGFP are indistinguishable and in good agreement with that obtained in Xenopus oocytes. Figure $4 C$ illustrates summarized data obtained from six HeLa-Cx47 and eight HeLa-Cx47-EGFP cell pairs. Junctional conductance declines steeply and nearly symmetrically at approximately $V_{j}=0 \mathrm{mV}$ over a $V_{j}$ range of $25-55 \mathrm{mV}$ to reach a plateau
$G_{\text {min }}$ of $\sim 0.16 . V_{0}$ appears to be somewhat smaller than that in Xenopus oocytes, possibly because of series resistance problems associated with higher levels of expression in Xenopus oocytes. Boltzmann parameters are as follows: $V_{0}= \pm 40 \mathrm{mV}, A=0.2$ $\mathrm{mV}^{-1}$, and $G_{\min }=0.16$. Representative macroscopic junctional currents obtained from a HeLa-Cx47 cell pair are shown in Figure $4 D$. The time course of the reduction in $g_{j}$ is similar to that measured in Xenopus oocytes. Small, brief $V_{j}$ steps applied between the longer duration $V_{j}$ steps illustrate rapid recovery of current that follows reduction with applied $V_{j}$ values. The kinetic properties of $V_{j}$ dependence were the same in HeLa-Cx47-EGFP cell pairs (data not shown) and together with the steady-state data indicate that attachment of EGFP to the $\mathrm{C}$ terminal of $\mathrm{Cx} 47$ has no effect on $V_{j}$ gating.

\section{Chemical gating}

As part of the initial characterization of $\mathrm{Cx} 47$, we examined whether $\mathrm{Cx} 47$ junctions responded to the chemical uncoupling agents heptanol and $\mathrm{CO}_{2}$. Application of $2 \mathrm{~mm}$ heptanol to four HeLa-Cx47 and five HeLa-Cx47-EGFP cell pairs in which $g_{j}$ 
A

Figure 4. Voltage gating of homotypic $\mathrm{Cx} 47$ gap junctions in Xenopus oocytes $(A, B)$ and transfected HeLa cells $(C, D)$. $A$, Graph of initial and steady-state $G_{j}$ ( filled and open triangles, respectively) as a function of $V_{j}$. $G_{j}$ is $g_{j}$ normalized to its value at $V_{j}=0$. Data represent mean values obtained from five Xenopus oocyte cell pairs with maximum $g_{j}$ values $<10 \mu \mathrm{S}$. The solid line is the Boltzmann fit of the steady-state data (see text). $B$, Representative junctional currents for $V_{j}$ steps up to $\pm 120 \mathrm{mV}$ in $20 \mathrm{mV}$ increments. Upward and downward currents are elicited by negative and positive $V_{j}$ values, respectively. Calibration: $500 \mathrm{nA}, 2$ sec. $C$, Graph of steady-state $G_{j}$ as a function of $V_{j}$ in $\mathrm{HeLa}-\mathrm{Cx} 47$ ( filled circles) and HeLa-Cx47EGFP (open circles) cell pairs. $G_{j}$ is normalized as described in $A$. The solid line is a fit of the experimental data to the Boltzmann equation (see text). $D$, Examples of junctional currents in response to $\pm 30,50$, and 65 $\mathrm{mV} V_{j}$ steps applied to one cell of a HeLa$\mathrm{Cx} 47$ cell pair. Small, repeated positive and negative $20 \mathrm{mV} V_{j}$ steps were applied to the same cell in between the longer duration $V_{j}$ steps to regularly monitor $I_{j}$. wt, Wild type.

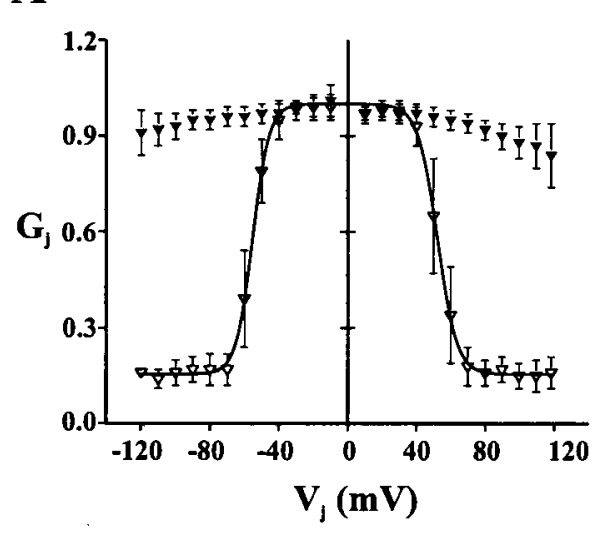

B

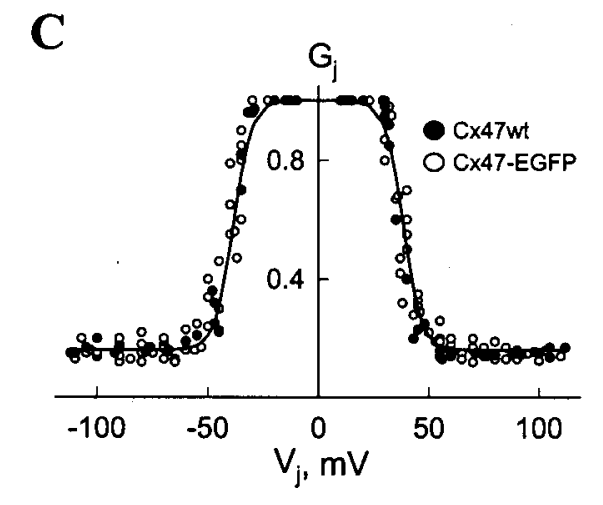

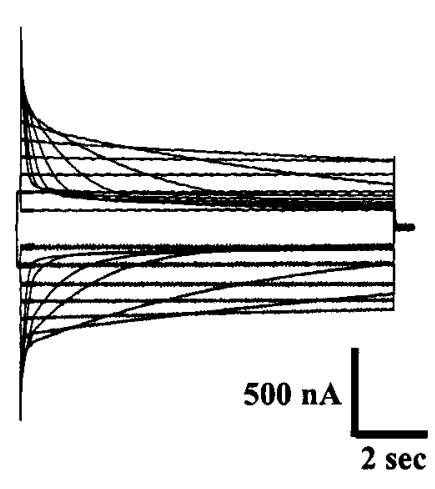

D

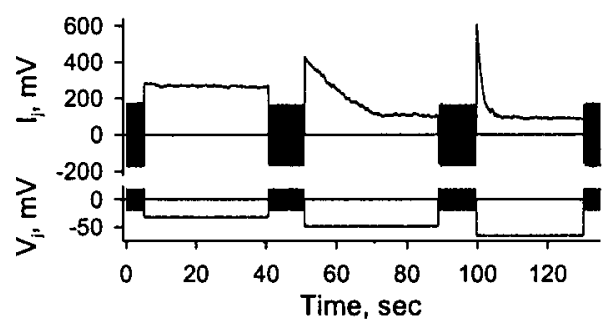

ranged from 5 to $15 \mathrm{nS}$ produced rapid and full uncoupling in each case. During washout, we observed recovery of $g_{j}$ that often took $\sim 50-60 \mathrm{sec}$ to reach $50 \%$ of the control value. Application of $100 \% \mathrm{CO}_{2}$ also produced rapid and full uncoupling in all tested HeLa-Cx47 $(n=5)$ as well as HeLa-Cx47-EGFP $(n=7)$ cell pairs. Coupling conductance recovered slowly during washout, taking 5-10 min to reach 50\% of the control value. Examples of uncoupling of HeLa-Cx47-EGFP cell pairs in response to these agents are shown in Figure 5, $A$ and $B$. Thus, we conclude that $\mathrm{Cx} 47$ exhibits properties similar to that of other members of the connexin family in response to heptanol and $\mathrm{CO}_{2}$ and that attachment of EGFP to the $\mathrm{C}$ terminal of $\mathrm{Cx} 47$ has no obvious influence on chemical gating by these agents.

\section{Conductance and permeability of Cx47 channels}

Single channels were examined in HeLa-Cx47 and HeLa-CX47EGFP cell pairs during recovery from uncoupling by $\mathrm{CO}_{2}$ or heptanol. Figure $5 C$ shows examples of dual whole-cell recordings of HeLa-Cx47 and HeLa-Cx47-EGFP cell pairs in which single channels were active during washout from $100 \% \mathrm{CO}_{2}$. Repeated voltage ramps applied to one cell of each pair revealed a linear $I_{j}-V_{j}$ relation over a large $V_{j}$ range $( \pm 100 \mathrm{mV})$. The singlechannel conductance of the open state obtained from the slope of the $I_{j}-V_{j}$ relation (Fig. $5 C$, solid lines) is $\sim 55 \mathrm{pS}$ in both $\mathrm{Cx} 47$ and Cx47-EGFP channels. During the voltage ramps, gating transitions were often evident between the fully open state and a long-lived substate with a conductance of $\sim 8 \mathrm{pS}$ (Fig. $5 C$, dashed lines). The ratio between the conductance of the substate and the fully open state is $\sim 0.15$, which corresponds to the $G_{\text {min }}$, mea- sured macroscopically. Thus it would appear that this substate is the residual subconductance state for $\mathrm{Cx} 47$ responsible for $G_{\min }$ as described previously for other gap junction channels (Bukauskas and Weingart, 1994; Moreno et al., 1994). Attachment of EGFP to the $\mathrm{C}$ terminal of $\mathrm{Cx} 47$ had no effect on single-channel conductance.

To examine whether larger molecules would pass through the Cx47 channels, permeability was examined by injecting Lucifer yellow (net charge, -2 ), DAPI $(+2)$, and neurobiotin $(+1)$ into one cell of a cluster of HeLa wild-type, HeLa-Cx47, and HeLaCx47-EGFP cells (Fig. 6). For the transfected cells, 10 min after injection, all first-order neighboring cells were stained, and tracer transfer was observed up to the fourth order of neighboring cells in the case of neurobiotin $(n=20)$. In HeLa parental cells, only $18 \%[ \pm 3.1 \%(\mathrm{SEM}) ; n=20]$ of first-order neighboring cells were stained, and tracer transfer was never observed beyond the first order of neighboring cells. No difference was observed between the coupling properties of HeLa-Cx47 and HeLa-Cx47-EGFP cells.

To assess dye permeability better as it relates to electrical coupling, we assessed $g_{j}$ and cell-to-cell transfer of dye in the same HeLa-Cx47 and HeLa-Cx47-EGFP cell pairs. Representative examples of these experiments are shown in Figure 7. The HeLaCx47-EGFP cell pair shown in Figure $7 A$ contained four junctional plaques. The phase-contrast image on the left shows the cell pair with two patch electrodes; the electrode for cell 1 was filled with Lucifer yellow. The fluorescence image (right) was taken 4 min after obtaining a whole-cell recording of cell 1 and shows 

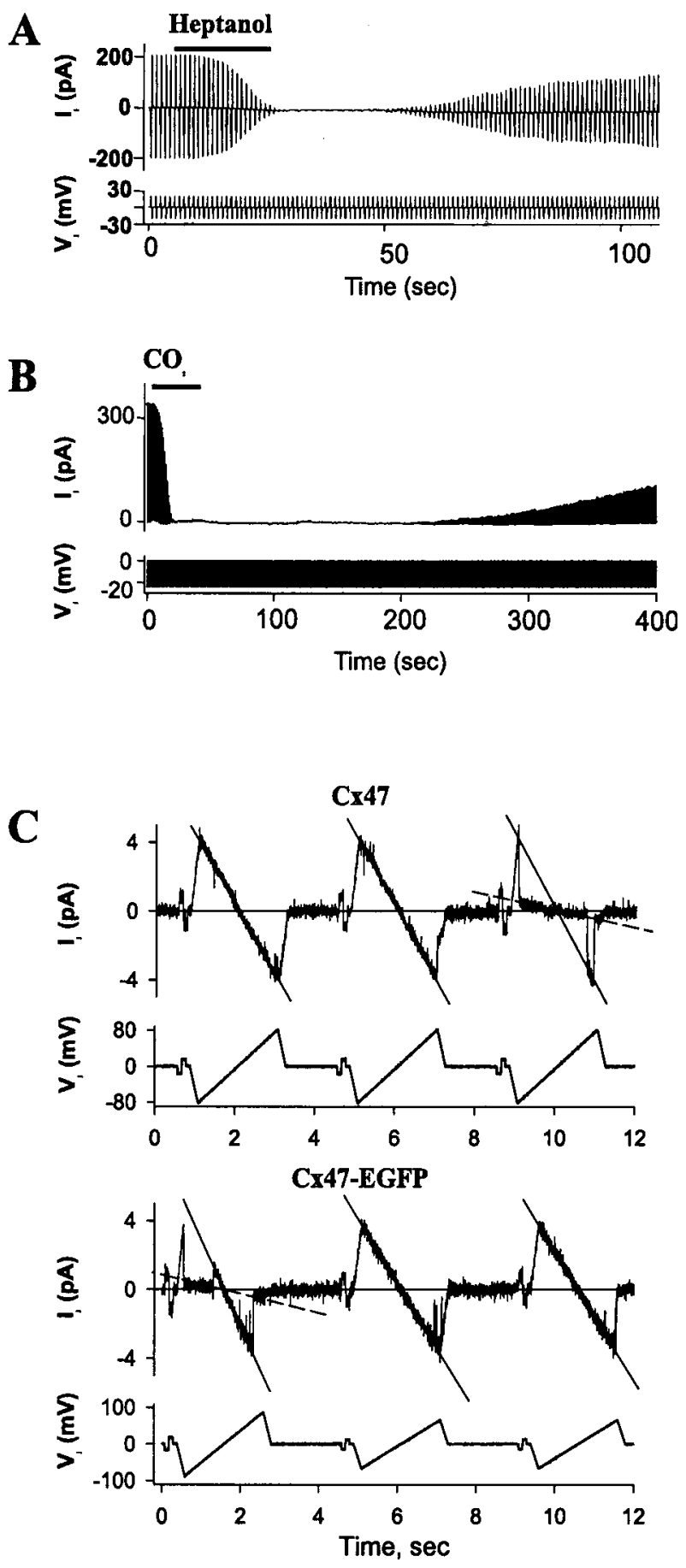

Figure 5. Chemical gating and single-channel conductance of $\mathrm{Cx} 47$ and Cx47-EGFP expressed in HeLa cells. $A, B$, Heptanol (2 mM) and $\mathrm{CO}_{2}$ uncouple Cx47-EGFP homotypic junctions in transfected HeLa cells. Junctional current $I_{j}$ was measured by applying repeated $V_{j}$ steps to one cell of a pair. A, Application of heptanol (horizontal bar) to a cell pair in which $g_{j}=10 \mathrm{nS}$ produced full uncoupling and relatively fast recovery after washout. $B$, Application of $100 \% \mathrm{CO}_{2}$ (horizontal bar) to a cell pair with $g_{j}=13 \mathrm{nS}$ fully uncoupled the cells within $\sim 20 \mathrm{sec}$, followed by slow recovery after washout. $C$, Illustration of $\mathrm{Cx} 47$ (top) and Cx47-EGFP (bottom) single-channel conductance and gating obtained in cell pairs during the early phase of recovery from full uncoupling with $100 \% \mathrm{CO}_{2}$ is shown. Records are of single-channel currents in response to repeated segments of $\pm 17 \mathrm{mV}, 200 \mathrm{msec} V_{j}$ steps followed by $\pm 65-85 \mathrm{mV}, 2 \sec V_{j}$ ramps. In both cases, a single-channel conductance of $\sim 55 \mathrm{pS}$ and a substate conductance of $\sim 8 \mathrm{pS}$ were approximated from the slopes of the $I_{j}-V_{j}$ relations (solid and dashed lines, respectively).

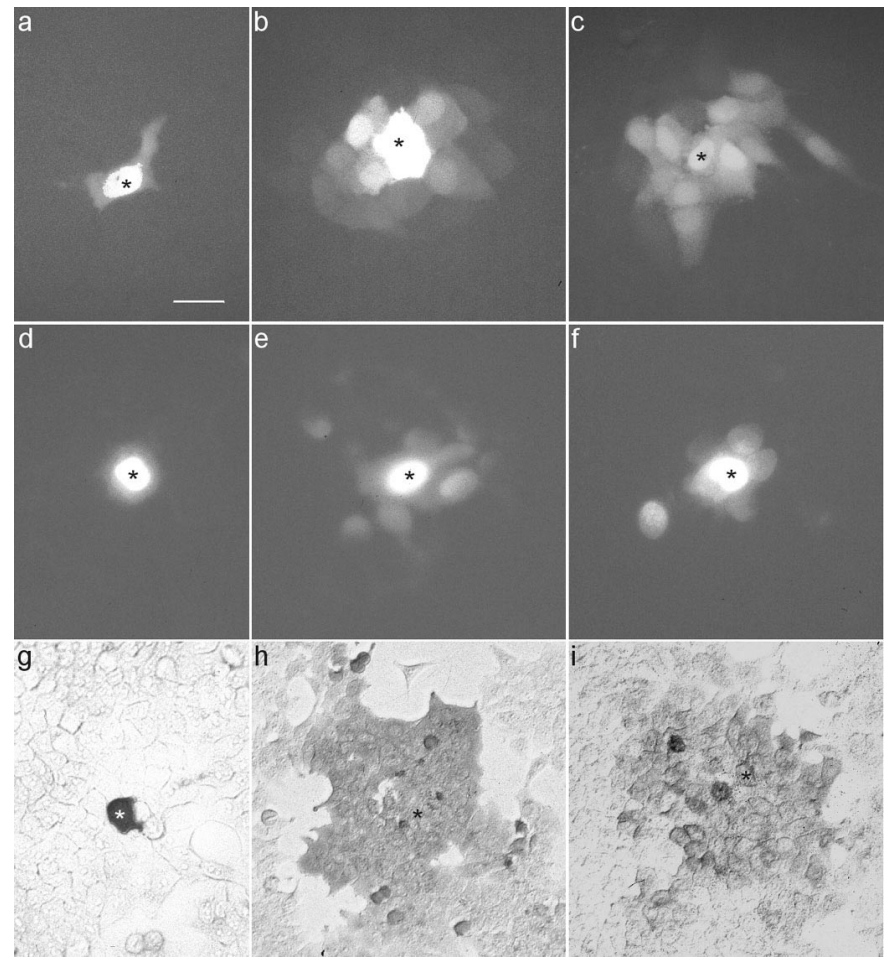

Figure 6. Tracer transfer in HeLa wild-type $(a, d, g)$, HeLa-Cx47 $(b, e$, $h$ ), and HeLa-Cx47-EGFP $(c, f, i)$ cells. The cells were injected with Lucifer yellow $(a-c)$, DAPI $(d-f)$, or neurobiotin $(g-i)$. Microphotographs were taken with the appropriate filter set or after fixing and staining in the case of neurobiotin. The injected cells are marked with asterisks. Scale bar: $a-g, 50 \mu \mathrm{m} ; h, i, 100 \mu \mathrm{m}$.

strong transfer of Lucifer yellow. Subsequent establishment of a whole-cell recording in cell 2 revealed a $g_{j}$ of $\sim 12 \mathrm{nS}$. Figure $7 B$ shows images of a cell pair with the electrode for cell 1 filled with DAPI. The two panels are as described in Figure $7 A$ except that the fluorescence image was obtained $10 \mathrm{~min}$ after establishing a whole-cell recording in cell 1 . Four large junctional plaques were present in the area of contact between these two cells (data not shown), and $g_{j}$ was measured to be $\sim 40 \mathrm{nS}$. Similar dye transfer results with Lucifer yellow and DAPI were obtained in all HeLaCx47-EGFP and HeLa-Cx47 cell pairs tested with $g_{j}$ values ranging between 10 and $40 \mathrm{nS}(n=12)$.

\section{DISCUSSION}

\section{Cx47 sequence analysis}

When comparing the mouse $\mathrm{Cx} 47$-coding sequence with those of other murine connexins, the highest similarity was found to the mouse $\mathrm{Cx} 45$ sequence (49\% identical amino acid residues). Also, both $C x 45$ and $C x 47$ are located on chromosome 11 in the mouse genome (Schwarz et al., 1992) (this work). Interestingly, the other neuronally expressed connexin $\mathrm{Cx} 36$ also has an unusually long putative cytoplasmic loop like $\mathrm{Cx} 47$. In this domain, the $\mathrm{Cx} 36$ sequence contains a glycine-rich stretch (amino acids 125-137), whereas $\mathrm{Cx} 47$ shows five adjacent proline residues at the homologous position (amino acids 136-140). Whether these features are of importance for the neuronal function of the connexins remains to be elucidated. Because of the sequence similarity between $\mathrm{Cx} 45$ and $\mathrm{Cx} 47$ we suggest to group these two connexins tentatively in the subclass $\gamma$ (cf. Goodenough et al., 1996; Söhl et al., 1998), although the genomic structure of $\mathrm{Cx} 47$ has not yet been investigated. 
A
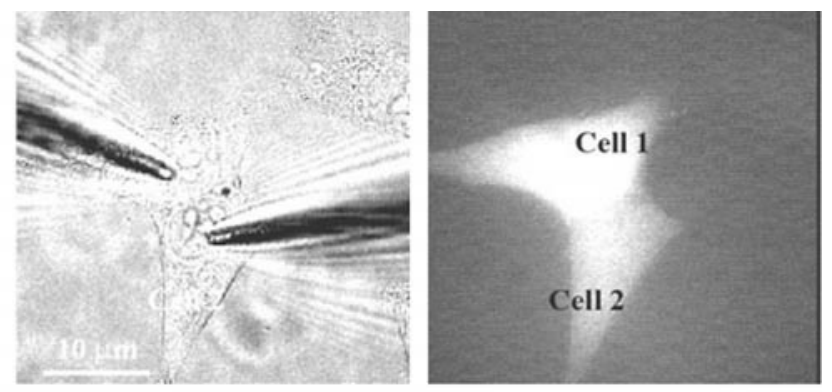

B
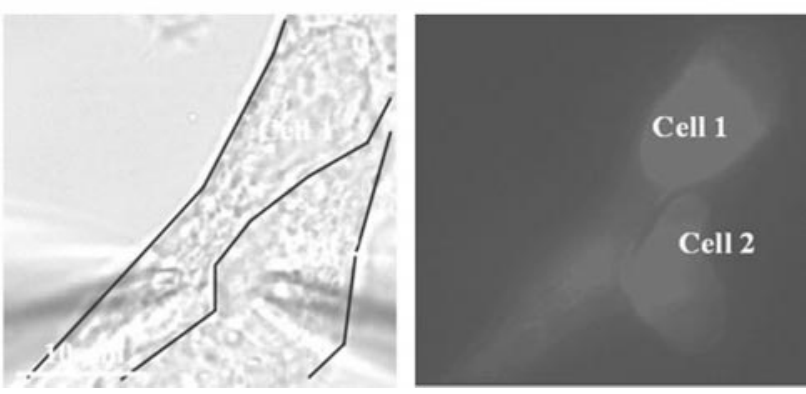

Figure 7. Simultaneous tracer transfer and double whole-cell recording between HeLa-Cx47-EGFP cells. $A$, Illustration of Lucifer yellow transfer between a single cell pair. Lucifer yellow was loaded into one of the cells (cell 1) through the patch pipette. The two panels show (from left to right) a phase-contrast image illustrating the positions of patch pipettes (left pipette was loaded with Lucifer yellow) and a fluorescence image taken with a filter set for Lucifer yellow 4 min after establishing whole-cell recording in cell 1 . After establishing a whole-cell recording in cell $2, g_{j}$ was determined to be $12 \mathrm{nS}$. $B$, Illustration of DAPI transfer between an electrically coupled cell pair. The two panels are as described in $A$ except that the fluorescence image for DAPI was obtained $10 \mathrm{~min}$ after establishing whole-cell recording in cell 1 and a filter set for DAPI was used. $g_{j}$ was measured to be $40 \mathrm{nS}$. DAPI preferentially labeled the nuclei of both cells.

\section{Cx47 expression pattern}

We have found a unique region-specific and developmentally regulated expression pattern of $\mathrm{Cx} 47$ by Northern blot analysis. Cx47 mRNA is most abundantly expressed in the spinal cord and the brain but, in contrast to $\mathrm{Cx} 45$ or $\mathrm{Cx} 36$, is not found in lung, heart, or retina. In brain, Cx47 mRNA was first detected 1 week after birth and increased thereafter, in parallel with myelination and synaptogenesis. Then, $\mathrm{Cx} 47$ transcripts reached a peak and decreased again in the adult mouse.

By in situ hybridization, we detected $\mathrm{Cx} 47$ expression in nerve cells reported previously to be electrically coupled (De Zeeuw et al., 1995, 1997; Chang et al., 1999; Prime et al., 2000; Traub and Bibbig, 2000) and in cerebellar Purkinje cells. It has to be shown that the Cx47 mRNA is translated into protein and leads to functional coupling in these cell types. The other neuronal connexin Cx36 is expressed in retinal neurons, among them amacrine AII cells (Feigenspan et al., 2001), whereas the retina is completely devoid of Cx47 mRNA, similar to the olfactory bulb, where Cx36 is expressed in the mitral and glomerular layer and scattered cells in the granular layer (Belluardo et al., 1999, 2000; Condorelli et al., 2000). The olfactory neuroepithelium differs from other brain areas in that neurogenesis continues to take place in the adult brain. The expression of $\mathrm{Cx} 36$ might be a hallmark of young neurons, because its mRNA precedes $\mathrm{Cx}^{4} 47$ mRNA expression by $\sim 2$ weeks. In the neocortex, we found $\mathrm{Cx} 47$ in situ hybridization signals in pyramidal neurons that have been described as intrinsic oscillating cells (Silva et al., 1991). Functions for electrotonic coupling in cortical cells could include an influence on circuit formation or cell migration (Nadarajah et al., 1997). Cx36 is expressed in the stratum pyramidale of the CA3 region, less in the strata pyramidale and radiatum of the CA1 region, and in the strata oriens and lacunosum-moleculare of the CA1 and CA3 regions. At the dentate gyrus, Cx36-positive cells were found in the stratum granulosum at the hilar border and the polymorphic zone of the hilus. This expression pattern is similar to that of $\mathrm{Cx} 47$, although the latter seems to occur more frequently in pyramidal neurons than in GABAergic interneurons. Within the cerebellum, Cx36 and $\mathrm{Cx} 47$ are coexpressed in Golgi cells, whereas basket cells were negative for $\mathrm{Cx} 47$ as shown by in situ hybridization. In several cells of brainstem nuclei and gray matter of the spinal cord, Cx36 and Cx47 could be detected, consistent with electrical coupling or gap junction structures that had been described in these areas (Rash et al., 1996; De Zeeuw et al., 1998; Chang et al., 1999).

Thus, the expression patterns of $\mathrm{Cx} 47$ and $\mathrm{Cx} 36$ partially overlap. Whether this difference in the pattern of expression is correlated with distinct functional properties of the two connexins remains to be examined in the future.

\section{Functional properties of $\mathbf{C x 4 7}$ channels}

As with most other connexins expressed in Xenopus oocytes or communication-deficient mammalian cell lines, $\mathrm{Cx} 47$ is able to induce strong electrical coupling that is sensitive to chemical uncouplers and $V_{j}$. $G_{j}$ declines steeply and symmetrically at approximately $V_{j}=0 \mathrm{mV}$ when $V_{j}$ values beyond $\pm 40 \mathrm{mV}$ are applied. Similar results were obtained in Xenopus oocytes injected with $\mathrm{Cx} 47$ cRNA and in HeLa cells transfected with $\mathrm{Cx} 47$ and Cx47-EGFP. The attachment of EGFP to the C terminal of $\mathrm{Cx} 47$ did not appear to alter the conductance, dye permeability, or gating properties of $\mathrm{Cx} 47$ examined at macroscopic and singlechannel levels. Thus, $\mathrm{Cx} 47$-EGFP channels should be particularly useful in studies of $\mathrm{Cx} 47$ localization in living cells as well as in electrophysiological studies of homotypic and heterotypic junctions where EGFP fluorescence facilitates screening of clones and the selection of cell pairs.

We should indicate that attachment of EGFP to Cx43, the only other connexin examined biophysically as a GFP fusion protein, similarly showed no effect on chemical gating, single-channel conductance, and dye permeability (Jordan et al., 1999; Bukauskas et al., 2000). However, unlike $\mathrm{Cx} 47$, attachment of EGFP to Cx43 substantially altered $V_{j}$ dependence (Bukauskas et al., 2000). This difference in the effect of attachment of EGFP to the $\mathrm{C}$ terminals of these two connexins may reflect a difference in the role of the C-terminal tail domain for $V_{j}$ gating (Revilla et al., 1999).

Single Cx47-EGFP channels were examined on washout after uncoupling with $\mathrm{CO}_{2}$ or heptanol and were found to have a unitary conductance of $\sim 55 \mathrm{pS}$. This unitary conductance is much higher than that of the other principal neuronal connexin, Cx36, for which a conductance of $\sim 15 \mathrm{pS}$ has been reported (Srinivas et al., 1999; Teubner et al., 2000). With both connexins abundantly expressed in certain neurons, it remains to be clarified whether this difference in unitary conductance is of functional significance. The differences in single-channel conductances of the two neuronal connexins may reflect their distinct permeabilities to larger molecules. $\mathrm{Cx} 47$ and Cx47-EGFP channel permeability was tested using dyes of similar size but different charge. Lucifer yellow, DAPI, and neurobiotin readily diffused between HeLaCx47 or HeLa-Cx47-EGFP cells. Thus, Cx47 channels are permeable to negatively charged dyes such as Lucifer yellow $(-2)$ 
and to positively charged tracers such as neurobiotin $(+1)$ and DAPI (+2), indicating no selectivity on the basis of charge. In contrast, although microinjected neurobiotin spread among HeLa-Cx36 cells, we did not detect transfer of Lucifer yellow or DAPI (Teubner et al., 2000; but see also Srinivas et al., 1999); recently, we observed intercellular transfer of ethidium bromide $(+1)$ in HeLa-Cx36 cells, consistent with the spreading of neurobiotin $(+1)$, but we saw no transfer of Alexa Fluor $350(-1)$ (F. F. Bukauskas and V. K. Verselis, unpublished observations). This difference may indicate that $\mathrm{C} \times 36$ channels preferentially allow intercellular diffusion of inorganic ions, whereas $\mathrm{Cx} 47$ channels seem to be less restrictive and may show preference to larger metabolites or second messengers.

\section{Diversity of connexins in neurons}

In many if not all types of the vertebrate cells, several connexins are expressed at the same time during development. Functional differences between connexins may only become obvious in vivo when different connexin mutants can be compared, for example in transgenic mice (cf. White and Paul, 1999; Willecke et al., 1999). Because neither $\mathrm{Cx} 36$ nor $\mathrm{Cx} 47$ mutants have been described, we can only speculate about physiological differences. For Cx36 hemichannels, no partner connexon has so far been identified that can form heterotypic gap junction channels with it when expressed in human HeLa cells or Xenopus oocytes (Al-Ubaidi et al., 2000; Teubner et al., 2000). It remains to be investigated whether Cx47 similarly shows a high degree of discrimination in heterotypic pairing.

Because of the overlapping expression of Cx36 and $\mathrm{Cx} 47$ in several brain regions, it will be of interest to examine whether Cx47 and Cx36 can form heterotypic junctions and whether these connexins can form heteromeric hemichannels in the same neuron. In those neurons, where $\mathrm{Cx} 36$ and $\mathrm{Cx} 47$ are coexpressed, they could fulfill complementary roles or respond to different regulatory mechanisms modulating electrical synapses. It is also possible that $\mathrm{Cx} 36$ and $\mathrm{Cx} 47$ are targeted to different synapses within the same neuron. The functional relevance of these speculations for the neurophysiology of electrical synapses can now be explored.

\section{REFERENCES}

Adamson MC, Silver J, Kozak CA (1991) The mouse homolog of the Gibbon ape leukemia virus receptor: genetic mapping and a possible receptor function in rodents. Virology 183:778-781.

Al-Ubaidi MR, White TW, Ripps H, Poras I, Avner P, Gomes D, Bruzzone R (2000) Functional properties, developmental regulation, and chromosomal localization of murine connexin36, a gap-junctional protein expressed preferentially in retina and brain. J Neurosci Res 59:813-826.

Belluardo N, Trovato-Salinaro A, Mudo G, Hurd YL, Condorelli DF (1999) Structure, chromosomal localization, and brain expression of human Cx36 gene. J Neurosci Res 57:740-752.

Belluardo N, Mudo G, Trovato-Salinaro A, Le Gurun S, Charollais A, Serre-Beinier V, Amato G, Haefliger J, Meda P, Condorelli DF (2000) Expression of connexin36 in the adult and developing rat brain. Brain Res 865:121-138.

Bennett MVL (2000) Seeing is relieving: electrical synapses between visualized neurons Nat Neurosci 3:7-9.

Beyer EC, Willecke K (2000) Gap junction genes and their regulation. In: Gap junctions. Advances in molecular and cell biology, Vol 30 (Hertzberg EL, Bittar EE, eds), pp 1-13. Stamford, CT: JAI.

Bittman KS, LoTurco JJ (1999) Differential regulation of connexin 26 and 43 in murine cortical precursors. Cereb Cortex 9:188-195.

Bukauskas FF, Weingart R (1994) Voltage-dependent gating on single gap junction channels in an insect cell line. Biophys J 67:613-625.

Bukauskas FF, Jordan K, Bukauskiene A, Bennett MLV, Lampe PD, Laird DW, Verselis VK (2000) Clustering of connexin 43-EGFP gap junction channels and functional coupling in living cells. Proc Natl Acad Sci USA 97:2556-2561.

Chang Q, Gonzales M, Pinter MJ, Balice-Gordon RJ (1999) Gap junc- tional coupling and patterns of connexin expression among neonatal rat lumbar spinal motor neurons. J Neurosci 19:10813-10828.

Condorelli DF, Parenti R, Spinella F, Trovato-Salinaro A, Belluardo N, Cardile V, Cicirata F (1998) Cloning of a new gap junction gene (Cx36) highly expressed in mammalian brain neurons. Eur J Neurosci 10:1202-1208.

Condorelli DF, Belluardo N, Trovato-Salinaro A, Mudo G (2000) Expression of Cx36 in mammalian neurons. Brain Res Brain Res Rev 32:72-85.

Dermietzel R, Traub O, Hwang TK, Beyer EC, Bennett MVL, Spray DC, Willecke K (1989) Differential expression of three gap junction proteins in developing and mature brain tissues. Proc Natl Acad Sci USA 86:10148-10152.

De Zeeuw CI, Hertzberg EL, Mugnaini E (1995) The dendritic lamellar body: a new neuronal organelle putatively associated with dendrodendritic gap junctions. J Neurosci 15:1587-1604.

De Zeeuw CI, Koekkoek SK, Wylie DR, Simpson JI (1997) Association between dendritic lamellar bodies and complex spike synchrony in the olivocerebellar system. J Neurophysiol 77:1745-1758.

De Zeeuw CI, Simpson JI, Hoogenraad CC, Galjart N, Koekkoek SKE, Ruigrok JH (1998) Microcircuitry and function of the inferior olive. Trends Neurosci 21:391-400.

Draguhn A, Traub RD, Schmitz D, Jefferys JGR (1998) Electrical coupling underlies high-frequency oscillations in the hippocampus in vitro. Nature 394:189-192.

Feigenspan A, Teubner B, Willecke K, Weiler R (2001) Expression of neuronal connexin36 in AII amacrine cells of the mammalian retina. J Neurosci 21:230-239.

Fukuda T, Kosaka T (2000) Gap junctions linking the dendritic network of GABAergic interneurons in the hippocampus. J Neurosci 20:15191528.

Galarreta M, Hestrin S (1999) A network of fast-spiking cells in the neocortex connected by electrical synapses. Nature 402:72-75.

Galarreta M, Hestrin S (2000) Burst firing induces a rebound of synaptic strength at unitary neocortical synapses. J Neurophysiol 83:621-624.

Gibson JR, Beierlein M, Connors BW (1999) Two networks of electrically coupled inhibitory neurons in neocortex. Nature 402:75-79.

Goodenough DA, Goliger JA, Paul DL (1996) Connexins, connexons, and intercellular communication. Annu Rev Biochem 65:475-502.

Green EL (1981) Genetics and probability in animal breeding experiments. New York: Oxford UP

Hennemann H, Schwarz HJ, Willecke K (1992) Characterization of gap junction genes expressed in F9 embryonic carcinoma cells: molecular cloning of mouse connexin31 and -45 cDNAs. Eur J Cell Biol 57:51-58.

Horst M, Harth N, Hasilik A (1991) Biosynthesis of glycosylated human lysozyme mutants. J Biol Chem 266:13914-13919.

Jordan K, Solan JL, Dominguez M, Sia M, Hand A, Lampe PD, Laird DW (1999) Trafficking, assembly, and function of a connexin43-green fluorescent protein chimera in live mammalian cells. Mol Biol Cell 10:2033-2050.

Manthey D, Bukauskas FF, Lee CG, Kozak CA, Willecke K (1999) Molecular cloning and functional expression of the mouse gap junction gene connexin-57 in human HeLa cells. J Biol Chem 274:14716-14723.

Moreno AP, Rook MB, Fishman GI, Spray DC (1994) Gap junction channels: distinct voltage-sensitive and -insensitive conductance states. Biophys J 67:113-119.

Nadarajah B, Jones AM, Evans WH, Parnavelas JG (1997) Differential expression of connexins during neocortical development and neuronal circuit formation. J Neurosci 17:3096-3111.

Neyton A, Trautmann A (1985) Single-channel currents of an intercellular junction. Nature 317:331-335.

O'Brien J, Bruzzone R, White TW, Al-Ubaidi MR, Ripps H (1998) Cloning and expression of two related connexins from the perch retina define a distinct subgroup of the connexin family. J Neurosci 18:7625-7637.

Parenti R, Gulisano M, Zappala A, Cicirata F (2000) Expression of connexin36 mRNA in adult rodent brain. NeuroReport 11:1497-1502.

Prime G, Horn G, Sutor B (2000) Time-related changes in connexin mRNA abundance in the rat neocortex during postnatal development. Dev Brain Res 119:111-125.

Rash JE, Dillman RK, Bilhartz BL, Duffy HS, Whalen LR, Yasumura T (1996) Mixed synapses discovered and mapped throughout mammalian spinal cord. Proc Natl Acad Sci USA 93:4235-4239.

Rash JE, Yasumura T, Dudek FD (1998) Ultrastructure, histological distribution, and freeze-fracture immunocytochemistry of gap junctions in rat brain and spinal cord. Cell Biol Int 22:731-749.

Rash JE, Staines WA, Yasumura T, Patel D, Furman CS, Stelmack GL, Nagy JI (2000) Immunogold evidence that neuronal gap junctions in adult rat brain and spinal cord contain connexin-36 but not connexin-32 or connexin-43. Proc Natl Acad Sci USA 97:7573-7578.

Revilla A, Castro C, Barrio LC (1999) Molecular dissection of transjunctional voltage dependence in the connexin-32 and connexin-43 junctions. Biophys J 77:1374-1383.

Rubin JB, Verselis VK, Bennett MVL, Bargiello TA (1992) Molecular 
analysis of voltage dependence of heterotypic gap junctions formed by connexins 26 and 32. Biophys J 62:183-193.

Schwarz HJ, Chang YS, Hennemann H, Dahl E, Lalley PA, Willecke K (1992) Chromosomal assignments of mouse connexin genes, coding for a gap junctional protein, by somatic cell hybridization. Somat Cell Mol Genet 18:351-359.

Silva LR, Amitai Y, Connors BW (1991) Intrinsic oscillations of neocortex generated by layer V pyramidal neurons. Science 251:432-435.

Söhl G, Degen J, Teubner B, Willecke K (1998) The murine gap junction gene connexin36 is highly expressed in mouse retina and regulated during brain development. FEBS Lett 428:27-31.

Srinivas M, Rozental R, Kojima T, Dermietzel R, Mehler M, Condorelli DF, Kessler J, Spray DC (1999) Functional properties of channels formed by the neuronal gap junction protein Connexin36. J Neurosci 19:9848-9855.

Sutor B, Schmolke C, Teubner B, Willecke K (2000) Myelination defects and neuronal hyperexcitability in the neocortex of connexin32-deficient mice. Cereb Cortex 10:684-697.

Teubner B, Degen J, Söhl G, Güldenagel M, Bukauskas FF, Trexler EB, Verselis VK, De Zeeuw CI, Lee CG, Kozak CA, Petrasch-Parwez E, Dermietzel R, Willecke K (2000) Functional expression of the murine connexin36 gene coding for a neuron specific gap junctional protein. $\mathbf{J}$ Membr Biol 176:249-262.

Thomson AM (2000) Chemical and electrical interneuron coupling. Curr Biol 10:R110-R112.

Traub RD, Bibbig A (2000) A model of high-frequency ripples in the hippocampus based on synaptic coupling plus axon-axon gap junctions between pyramidal neurons. J Neurosci 20:2086-2093.

Verselis VK, Ginter CS, Bargiello TA (1994) Opposite voltage gating polarities of two closely related connexins. Nature 368:348-351.

White TW, Paul DL (1999) Genetic diseases and gene knock outs reveal diverse connexin functions. Annu Rev Physiol 61:283-310.

Wilders R, Jongsma HJ (1992) Limitations of the dual voltage clamp method in assaying conductance and kinetics of gap junction channels. Biophys J 63:942-953.

Willecke K, Kirchhoff S, Plum A, Temme A, Thönnissen E, Ott T (1999) Biological functions of connexin genes revealed by human genetic defects, dominant negative approaches and targeted deletions in the mouse. Novartis Found Symp 219:76-88.

Yamamoto T, Hertzberg EL, Nagy JI (1990) Epitopes of gap junctional proteins localized to neuronal subsurface cisterns. Brain Res 527:135139. 